\title{
Roundtable
}

\section{Inquietudes: On Location and Diaspora - Evelyn Hu-Dehart, Christopher Lee, C.X. George Wei, Marcela Canizo, Cecilia Onaha, Loz, Paula Hoyos Hattori, and Richard Fung}

\author{
Introduction by Ana Paulina Lee \\ Columbia University, New York, NY, USA \\ ana.lee@columbia.edu \\ Anna Kazumi Stahl \\ New York University (Global Program, NYU Buenos Aires, Argentina) \\ aks5@nyu.edu
}

For this forum, we asked scholars and artists based throughout the hemispheric Americas to reflect on how the framework of location affects or limits their work on Asian diasporas. Invitations were delivered to practitioners working in diverse parts of the world, as well as in various disciplines and on quite divergent topics. Undeniably, the notion of geography lends itself to an imagined mapamundi of hegemonies, yet individual processes reveal multiple possible positionings within set locations. It became abundantly evident that we would come upon not only peripheral voices in hegemonic centres but also hegemonic voices or practices still afoot in marginal locations. Hence, inquietude seems a key analogy for what has motivated and driven this roundtable. Inquietudes brings forth the notion of being in movement, of shuffling or shuttling between points of quietude, touching on them by turns and then continuing to others, bouncing here and there, between and among many. This analogy is less about an idealized and intentionally stabilizing discourse, like that of multiculturalism; rather, it is more concerned with new, polycentric praxes that do not idealize the conflation of diverse points in a stable combination. 
It prefers the "revolving optics" mode of analysis that engages multiple perspectives simultaneously, each with its turn as fulcrum, giving its particular lay of the land.

The responses have been left in their original languages in order to preserve the multilingual and multi-sited relation of the local to the global. The polyphonic voices in this forum provide multiple perspectives on how one's location and experience with mobility or diaspora may reveal the layered aspects of memory, globalization, capitalism, and migration.

Evelyn Hu-Dehart: My interest in the Chinese diaspora started with location, but location as the result of travel. I was a sophomore at Stanford University when I was selected to participate in a summer study program in Brazil. While in Brazil, I had the proverbial life-changing experience. First, Brazil took me to a whole different world than the one I was born in, China, the world that I grew up in, California, and took me to another part of the world, Latin America/South America. What I did not expect to find in Brazil, however, were Asians - Japanese, Chinese, and Arabs. That was a revelation, and caused me to wonder how - and why - they arrived in the Americas. It turns out there are rich narratives about Asian migrations to Latin America and the Caribbean beginning in the Ming dynasty, when Chinese from coastal areas of South China settled in Spanish Manila. I also learned in Brazil that location informs identity, and explains identity formation. When we visited a place in southern Brazil settled by German immigrants, I met an African Brazilian who was raised by German speakers in that community. As I had just returned from study abroad in Germany, my German was better than my Portuguese at the time, so we-a Chinese American and an African Brazilian-conversed in German, our common language. When we parted, he took me by total surprise when he announced: "Wir Deutschen mussen zusammenbleiben [We Germans must stick together]!" Years later, I was finally able to understand his insight — that our identities are in part formed by the context of our experiences, that is, identities are socially constructed and historically contingent, and not simply a reflection of our phenotypical characteristics. This is another reminder that location matters: location in terms of place and time.

Location can be a limiting factor if fixed. In other words, one does not learn about the Chinese diaspora initially from books, but from encounters. Diasporas, by definition, are about movement and mobility, the result of migration, displacement, banishment, expulsion, and exile. In the case of the Chinese 
diaspora, which is the one I know best, it is truly a worldwide phenomenon spanning more than five centuries that continues to this day. So it is by following the multi-stranded tracks of Chinese movement and settlement around the world that one gets a full measure of this incredible phenomenon. I could not have studied Chinese diasporic experiences in Peru, Mexico, Cuba, and Jamaica without locating myself in those places for sustained periods of time, not only to use local archives, but to know the communities, observe everyday activities, appreciate the cultures, meet leaders and personalities, and listen to the cadences of language, even if superficially. That is why I have relocated myself during my current sabbatical in Singapore - the heart of modern Southeast Asia-with a Chinese-dominant local culture and Chinese-controlled political system, the reverse of diasporic conditions everywhere else Chinese have historically been, an ethnic minority negotiating tenuous peace with nationalistic majority-controlled states and resentful natives. Most diasporic communities in Southeast Asia (Singapore, Indonesia, Myanmar, Vietnam) exist in recently created nation-states carved from European trading colonies and extractive economies, in sharp contrast to the white, anglophone settler societies of the United States, Canada, Australia, and New Zealand, with a variant in Catholic Latin America.

Christopher Lee: As Evelyn Hu-Dehart wrote recently, "diasporas describe relationships and human drama across time and space, that is, history itself." What happens, then, when the relationships and dramas of history come together in a specific time and space? The West Coast of what is now British Columbia [Canada] became a settler colony in the mid-nineteenth century through the violent subjugation and dispossession of Indigenous peoples. The colonial order that ensued required migrations of people from different continents in the service of an extractive economy, but these histories have largely been domesticated through narratives of nation building and belonging. If these narratives must be unravelled to come to terms with deeply sedimented injustices, then the challenge of diaspora critique is to think synchronically and diachronically at once. In my teaching, this has meant emphasizing how social practices thought to be "local" (community organizations in Chinatown, for example) historically emerged in multiple diasporic sites connected through transportation and communication networks. This perspective resonates with my students' increasingly transnational lives, enabling them to connect their own experiences across time and space, and thereby displace the

1 Evelyn Hu-Dehart, "Diaspora," in Keywords in Asian American Studies, edited by Linda Trinh Vo, Cathy J. Schlund-Vials, and K. Scott Wong (New York: New York University Press, 2015), 53. 
multicultural frameworks that we have inherited from settler colonialism, frameworks that implicitly—and at times explicitly—demand assimilation as the primary means of social belonging.

The temptation of exceptionalism is always lurking around the corner. Even without the bluster or arrogance that sometimes accompanies exceptionalism, the challenge of a diasporic perspective is to hold onto the local and global at once, a task that does not necessarily translate into existing structures of knowledge. For Asian Canadian Studies, the challenge is to attend to the fluidities of both "Asia" and "Canada" despite the tendency to take one or both terms for granted. For example, accounts of Asian migration in Canada have largely focused on racialization and white supremacy. This approach inevitably (if inadvertently) centres the settler nation by making it the primary context against which notions of Asianness emerge, thereby framing the entire field as a nation-specific formation that emphasizes the uniqueness of Canadian experiences compared to other national sites. The point is not to deny the specificity of such experiences but rather to question the nation as the organizing principle of sociocultural knowledge. Diasporic communities, after all, did not and do not orient their lives solely around a national imaginary. Rather, they contend with the structural inequalities of the world system as they cathect around categories of nation, class, status, gender, and so on. My sense is that the tremendous angst about national belonging and citizenship that arguably characterized certain moments of Asian Canadian cultural production resonates uneasily with my students today, whose lives are informed by the displacements of a global age. A diasporic approach offers alternative genealogies of their personal experiences that refuse to posit contemporary Canada as a temporal or spatial exception.

C. X. George Wei: In the 196os, Ruth Hill Useem, an American sociologist, put forth the concept of so-called "Third Culture Kids" (TCKs), namely individuals who lived in a foreign land and culture for a substantial period of time. Experiences of this sort blend native culture with foreign culture to create a third culture, hence, TCKs. In such cases, the First Culture is the individual's native culture, or the cultural and social environment of the motherland in which they grew up; the foreign culture or environment the individual migrates to and lives in for an extended period of time is considered to be the Second Culture; and the Third Culture is the new culture created by a тСК who accepts and adopts the second culture, and fuses the first and second cultures.

Useem's concept of TCKs could be applied to the life experiences of many immigrants, including my own Asian diaspora and learning experiences in America. I could use the basic concept of Third Culture to describe how the 
process of my history study was influenced by my relocation. There was the "First History" or "Native History" that I learned as the historical scholarship written and taught by historians who have virtually no direct contact with foreign cultures, or much experience living in a foreign country, and whose minds are framed almost entirely by their native cultures. The "Second History" refers to the history I learned from foreign historians who have a cultural background different from my native culture, and who have had limited direct contact with cultures outside their own country. In other words, the "First History" to an American student is the "Second History" to a non-American student, like me. Finally, the "Third History" is reserved for scholarship written and taught by historians who grew up in the First Culture and were educated by the First History but who also lived in the Second Culture and studied the Second History, and so are able to transcend whatever traps might be associated with the First History and the Second History. The challenges that I faced, and the transformation of my mind that occurred during my learning and working experience in the us since 1988, reflect exactly the progress of learning the Third History, which could never be achieved through books, classrooms, and the First Culture experience. It was the shocks and challenges that I experienced in America, and my learning, adjusting, and adapting to American society and the Second Culture that truly allowed me to walk out of the First Culture and the First History, to realize their limitations, and to gain a true sense of the Third Culture and Third History.

Just as not every тск could have a sober view of the limitation of the First Culture and First History, neither is every Chinese historian in America or every American scholar with or without the Tск experience able to clearly see the boundaries of the First Culture and First History, especially considering that the majority of the local peoples do not have global migration experience. As a result, most people-including scholars-are trapped in their First Culture and First History. For instance, many American scholars thought that nationalism was purely a product of the Communist propaganda through education and media, and blamed the Chinese Communists for every nationalist action by Chinese people. This kind of perspective is ahistorical. It is true that the Communist government of China uses nationalism as a means to consolidate the nation and their rule over China. However, the seed of Chinese nationalism is, in fact, deeply rooted in China's past. It is mainly the historical failures, humiliations, and injustices imposed by imperialist powers upon the Chinese people since the First Opium War that engendered nationalism.

Yet many Western scholars do not fully understand the source of Chinese nationalism. They lack a sense of history, or the perspective of the Second History, remaining confined by their First History perspective and the values 
and standards of the First Culture. Likewise, many Chinese historians do not understand American concern about Chinese nationalism either, but blame the American government's imperialist actions against China. To amend this situation, I have often had to play a role of devil's advocate, either in China or America: I tried to be an American in China and a Chinese in America, to discuss things with Chinese with an American approach, or explain things to Americans from the Chinese perspective, regardless of the fact that the views on both sides are often in conflict, in order to help Chinese have a better understanding of Americans, or vice versa. According to a Chinese saying, I am "not a good person within or without the circle" since it's very hard to change the views of most Americans and Chinese people who rarely have close contact, and whose perception of the other has been fixed by traditional media and education. In one case, I was even cursed by an old Chinese man as being an "American imperialist running dog" because he was very angry with the American students for their behaviour on a train, even though I tried to calm him by explaining the different culture and customs of America.

Marcela Canizo: He desarrollado mi actividad fundamentalmente en Brasil, y luego en Argentina, lo que ha dado como resultado dos experiencias diferentes de trabajo. En el caso brasileño, existe una dimensión cotidiana, dado que el volumen inmigratorio asiático fue significativamente mayor, y con una gran concentración social en las ciudades. Las características de la identidad brasileña como una antropofagia de diversas culturas, desde la asiática hasta la africana, pasando por la europea y la indígena, le da al trabajo de investigación una impronta local muy acentuada y un intercambio muy activo entre las comunidades locales y los lugares de origen, que, en relación con mi trabajo estuvo focalizado en Japón.

En el caso argentino, las características de formación de identidad no estuvieron tan marcadas por la mezcla de culturas sino por la tradición colonial y las dicotomías resultantes de ella, como el eje civilización-barbarie, o el centralismo europeo versus el otro, lo cual ofreció históricamente otro corpus de trabajo más ligado a la cuestión orientalista, si consideramos como tal la perspectiva establecida por Said para los estudios post coloniales. La tradición literaria argentina ha sido muy productiva en este sentido. Todavia creo existe un enorme campo de trabajo en lo relacionado con cultura visual, que es mi área de investigación.

Precisamente entiendo que el lugar de uno puede ofrecer oportunidades muy interesantes de trabajos originales sobre temas no abordados hasta el momento.

Cecilia Onaha: Me considero como alguien que trabaja sobre diáspora asiática. Abarca en términos generales coreanos y chinos superficialmente-a partir de 
la observación de sus casos y en particular y más profundamente, el caso de los japoneses. Dudo de llamar al caso de los japoneses de "diáspora," por lo menos en lo que se refiere al área geográfica en donde los observo, que es la Argentina. Esto tiene que ver con la particularidad de este país, que buscó desde un principio asimilarlos y que finalmente, después de más de cien años de presencia, terminó integrándolos. Y es en este sentido en que el lugar geográfico impacta sobre mi trabajo. Este lugar, la Argentina, con una historia particular respecto de la forma de recepción e inserción de las comunidades de inmigrantes, hace que cuestiones las teorías más generalizadas respecto de los estudios de migración, multiculturalidad e interculturalidad.

La "diáspora" o en el caso de la comunidad japonesa, tiene que ver hoy en día con redes internacionales, canales de comunicación con la comunidad de origen $\mathrm{u}$ otros puntos en el globo con comunidades análogas, y siempre se encuentran recursos para realizar el relevamiento de otros puntos de radicación de comunidades del mismo origen, a los efectos de comparar y tener una visión más amplia.

LOZ: Minha condição de imigrante chinês no Brasil me levou a uma certa atitude de abertura e flexibilidade na aceitação de outras identidades culturais,

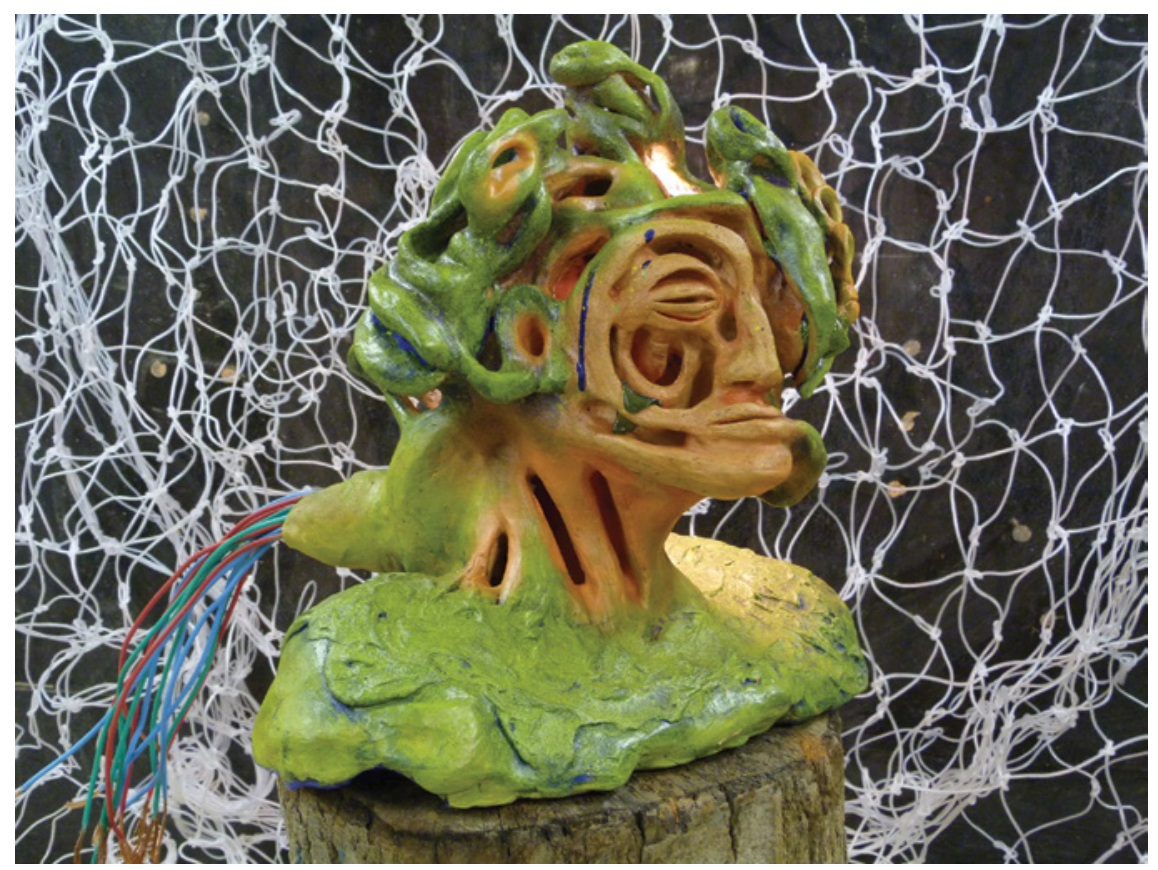

FIGURE 1 LOZ (Chiu Yi Chih and Irael Luziano), ALEPH, 2015. Mixed media, $40 \times 45 \times 60$ centimetres.

IMAGE COURTESY OF THE ARTISTS 


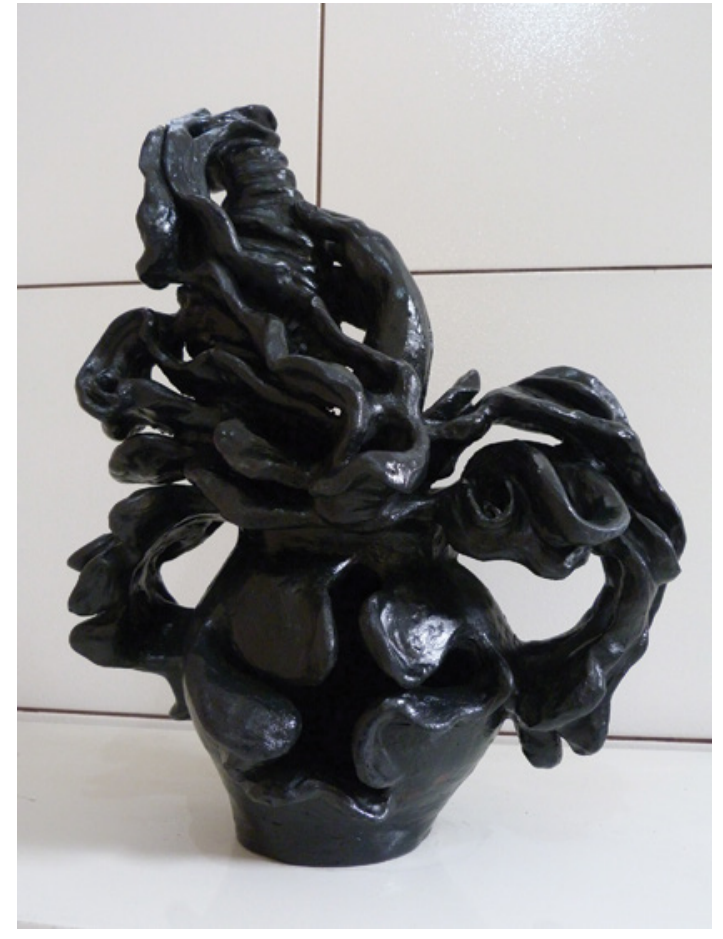

FIGURE 2

LOZ (Chiu Yi Chih and Irael Luziano), вIоcosmic, 2015. Mixed media, $50 \times 40 \times 25$ centimetres. IMAGE COURTESY OF THE ARTISTS

mas, ao mesmo tempo, foi um processo que implicou, no meu caso, a me ver como um "outro," no sentido de uma alteridade singular. Era como se eu nem fosse chinês nem brasileiro, e estivesse numa espécie de zona limítrofe, de devir mutante, o que significa que na arte que desenvolvo atualmente com o artista brasileiro Irael Luziano pude perceber o quanto essa ambiguidade mesma desdobrava-se no próprio modo de construir a arte. Ao me juntar a ele no LOZ, isso significou uma grande mudança e enriquecimento de nossas possibilidades artísticas. Não se trata apenas de uma parceria momentânea, mas de uma fusão onde somos uma dupla instigada pelas mesmas questões, e que pelo fato de estarmos em caminhadas constantes entre São Paulo e Embu das Artes, potencializamos nossa forma de realizar a arte do LOz. Nesse sentido, o crítico Claudio Willer observa com perspicácia no prefácio escrito para nosso livro inédito "Metacorporeidade" publicado pela Editora Córrego: “(...) Livro híbrido? Certamente. Entre as acepções ou sentidos que o termo hibridismo vem tomando atualmente, é fusão ou convivência de diferença; realização do multiculturalismo, atmosfera cujo o ar o sino-brasileiro Chiu Yi Chih respira. E desafio ao princípio lógico da identidade e não-contradição. Cabe lembrar as observações de uma cientista natural, além de poeta e ensaísta, Maria Estela 


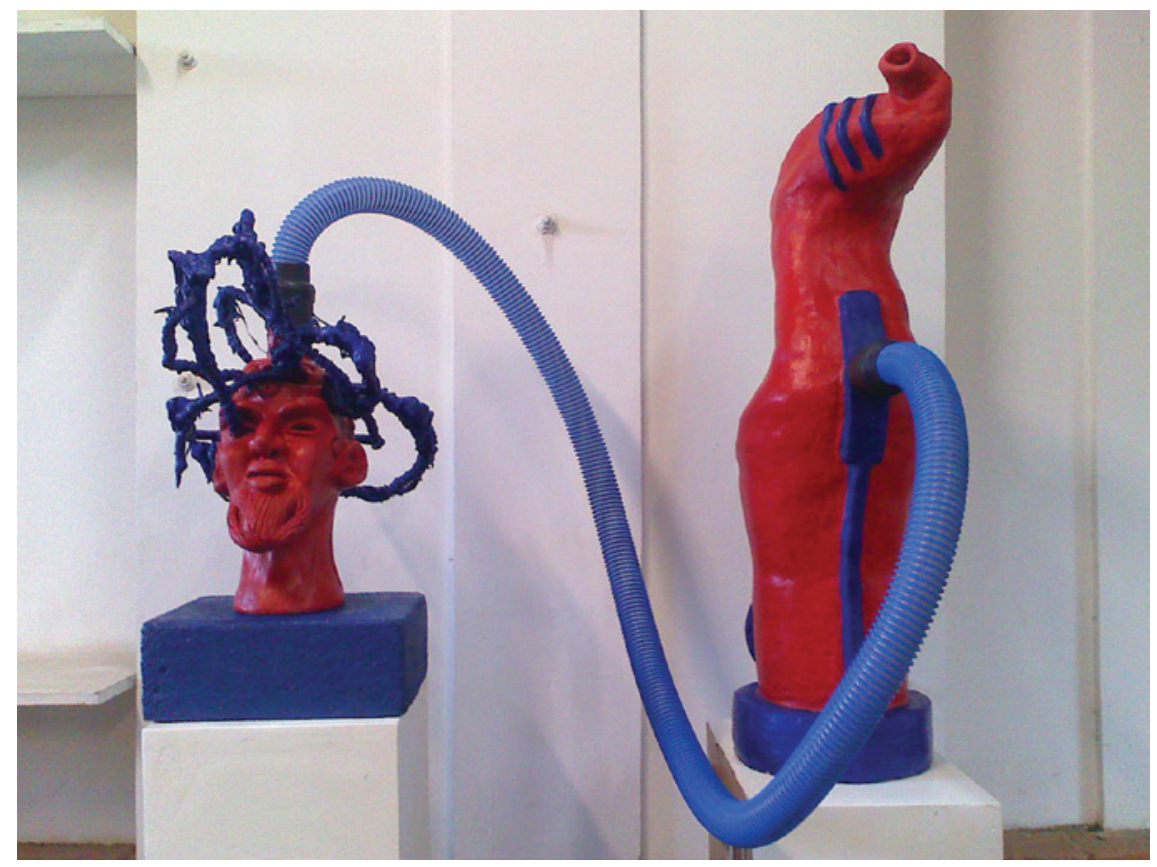

Figure 3 LOZ (Chiu Yi Chih and Irael Luziano), Philomundus, 2013. Mixed media, $27 \times 32 \times$ 57 centimetres.

IMAGE COURTESY OF THE ARTISTS

Guedes, sobre o hibridismo como ordem natural ou princípio ativo no ensaio 'A obra ao rubro,' examinando Herberto Helder, argumenta que todas as formas de vida são híbridas. Passando da esfera das coisas para aquela dos símbolos, afirma: 'É o gênio poético que hibrida'. Em outras palavras: o poeta é um demiurgo, cria mundos; a criação é pela hibridação e mestiçagem, replicando a ação da natureza, sob a regência de Eros que promove a união. Sob esse ângulo, os textos e imagens visuais - referindo-se às obras plásticas do $\mathrm{LOZ}$ - embora aparentemente enigmáticos, ou justamente naquilo que têm de aparente enigma, expressam uma poética."

O fato de eu residir no Brasil, e sobretudo, numa grande cidade como São Paulo e ter absorvido diversas leituras e vivências, como o encontro com os poetas Roberto Piva e Claudio Willer, além de ter participado com diversos artistas na área da poesia e das artes visuais, só intensificou um maior mergulho existencial. O LOZ, na pesquisa da Metacorporeidade, cria esculturas, pinturas, performances e poesias atentando-se para a imersão do corpo dentro dos múltiplos territórios suscitados pelo embate entre corpo e espaço. A cidade e suas zonas afastadas é como um plano onde se entrecruzam essas intersecções 


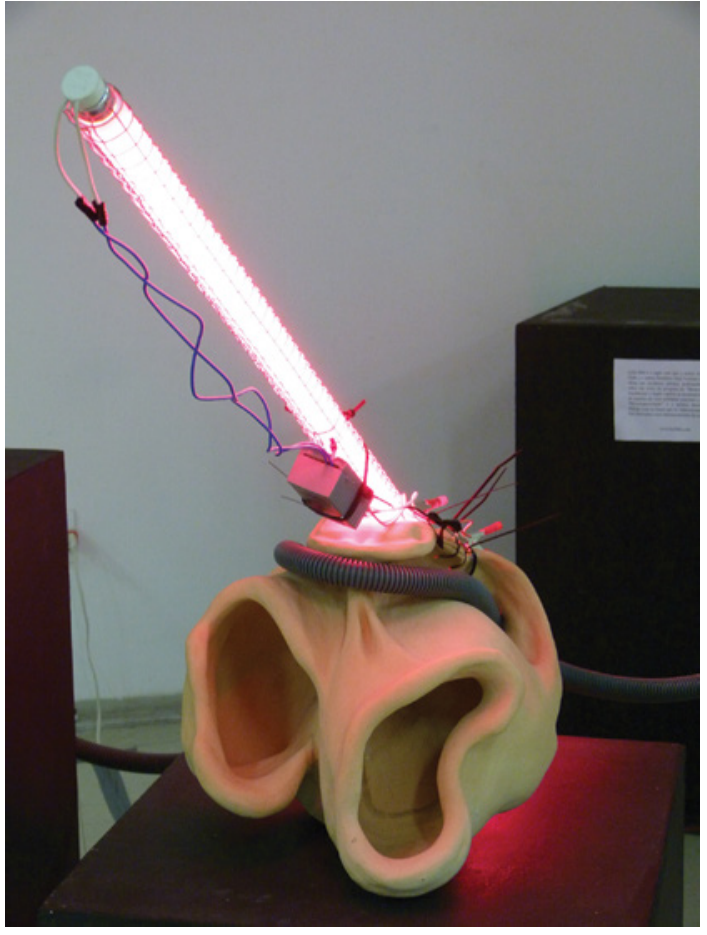

FIGURE 4

LOz (Chiu Yi Chih and Irael Luziano), TRANSCURSO, 2014. Mixed media, $45 \times 38 \times 36$ centimetres. IMAGE COURTESY OF THE ARTISTS

heterogêneas e onde criamos conexões infinitas. É por isso que pensamos que nossa arte se constrói em sintonia com o presente e com o lugar pelo qual somos afetados enquanto corpos sensíveis e híbridos. Somos "philomundus" (amantes dos mundos). Esse termo que foi criado pelo $\mathrm{LOZ}$ - assim como a palavra "metacorporeidade" - sugere um pouco de nossa pesquisa em que hibridizamos as matérias, cavando outros mundos e interseccionando com as diferenças e as mutações. Há uma imensa força avassaladora que nos precipita em direção a novos territórios.

Paula Hoyos Hattori: Trabajo como docente e investigadora en una universidad pública argentina. El lugar en el que vivo, la ciudad de Buenos Aires, impacta de diverso modo sobre esas actividades. La universidad es por definición un espacio político. De modo que las vicisitudes políticas o sociales, tanto a nivel nacional como universitario, también impactan en mi trabajo (dicto la materia "Literatura europea del Renacimiento"). Pensándolo bien, la necesidad de revisar el Renacimiento europeo desde una perspectiva global, que incluya críticamente el expansionismo europeo del siglo XVI, es también una cuestión política. 
El lugar en el que uno vive condiciona el trabajo de investigación (el asunto actual de mi investigación: el encuentro cultural entre Portugal y Japón en el siglo XVI). Prefiero decir que "condiciona" y no que "limita," pues creo que lo que en una primera impresión parece un límite, puede transformarse en una potencia. Por ejemplo, pensar el Renacimiento europeo, o el encuentro entre europeos y japoneses en el siglo XVI, desde Buenos Aires. A primera vista, puede parecer una empresa imposible, al imaginar la escasez de bibliotecas sobre esos asuntos, o la estrechez del campo académico específico... Sin embargo, el trabajo no sólo es posible, sino que el hecho de no pertenecer, por ejemplo, al campo de la historiografía portuguesa o jesuita sobre el tema, brinda un aire renovador a nuestra perspectiva. Podemos soslayar los quiebres y debates propios de cada tradición, para simplemente tenerlas como punto de partida y referencia.

Para terminar, si bien no investigo académicamente sobre la diáspora asiática, sí soy descendiente de japoneses, e intento mantener viva la memoria de mis abuelos. Al igual que muchos otros nietos o bisnietos de issei, participo en las asociaciones de inmigrantes ya centenarias, que no buscan únicamente conservar tradiciones niponas, sino que procuran pensar activamente la identidad nikkei, que es por definición mixta. Entonces, el lugar al que llegaron mis abuelos, el espacio que eligieron para vivir y yo también, impacta sin dudas, no solo sobre mi trabajo cotidiano como docente e investigadora, sino sobre la construcción de mi propia identidad.

Richard Fung: Within the framework of Asian diaspora we look at transnational connections, but culture and identity manifest in particular ways in specific sites. As I prepare to fly from Toronto to my native Trinidad and Tobago, I can affirm that location affects what I do. I am aware that if I call myself Asian in Port of Spain I will face puzzled looks. There, I am Chinese, and the largest ethnic group is Indian, not South Asian. Whenever you hear pan-ethnic terms on the islands, you know you're speaking to international—not local—ears, as the conditions for pan-ethnic "Asian" alliances are absent. Much of my work is inspired by my journeys across and between geopolitical spaces.

If I think about the two most significant Chinese Trinidadian artists of the twentieth century, Sybil Atteck and Carlyle Chang, their themes and artistic idioms are very much engaged with the local in the period leading up to, and just after, independence from Britain. Their work exemplifies how global currents surface in the local-for example, Atteck's assimilation of Max Beckman's expressionism, which would become a national style. Even when Atteck and Chang feature identifiable Chinese references-portraits of friends and family for the former, carnival costumes for the latter - theirs is a 




FIGURE 5 Richard Fung, The Way to My Father's Village, 1988. Film (still), 38 minutes. IMAGE COURTESY OF THE ARTIST.

distinctly Trinidadian engagement. In fact, both would likely resist being framed through a lens of Asian diaspora rather than as people of Trinidad and Tobago, or the Caribbean.

Rather than limit, I would say that location shapes our engagement with Asian diasporic experience. I am struck by how my relatives, upon emigration, assume the modes of identity, culture, and politics of their adopted homes, even as they may retain elements of their Trinidadian formation and traces of their various ethnic lineages. Whereas the Chinese component of mixed-race peoples often defines how they are viewed in Trinidad and Tobago on moving to, say, Britain or North America, they often find themselves either racially illegible (including to other Asians) or else defined by what become more salient components of their heritage. I've noted, for instance, how my half-African first cousins living in North America, and especially their children, become Black. Their Chinese roots may have an emotional place in their lives, but do not define the ways they function in society.

If I could foreground the transnational now, it's important to also understand how - even in "insular" locations like Trinidad and Tobago-identities and experiences are shaped and interpreted through global intimacies, to 


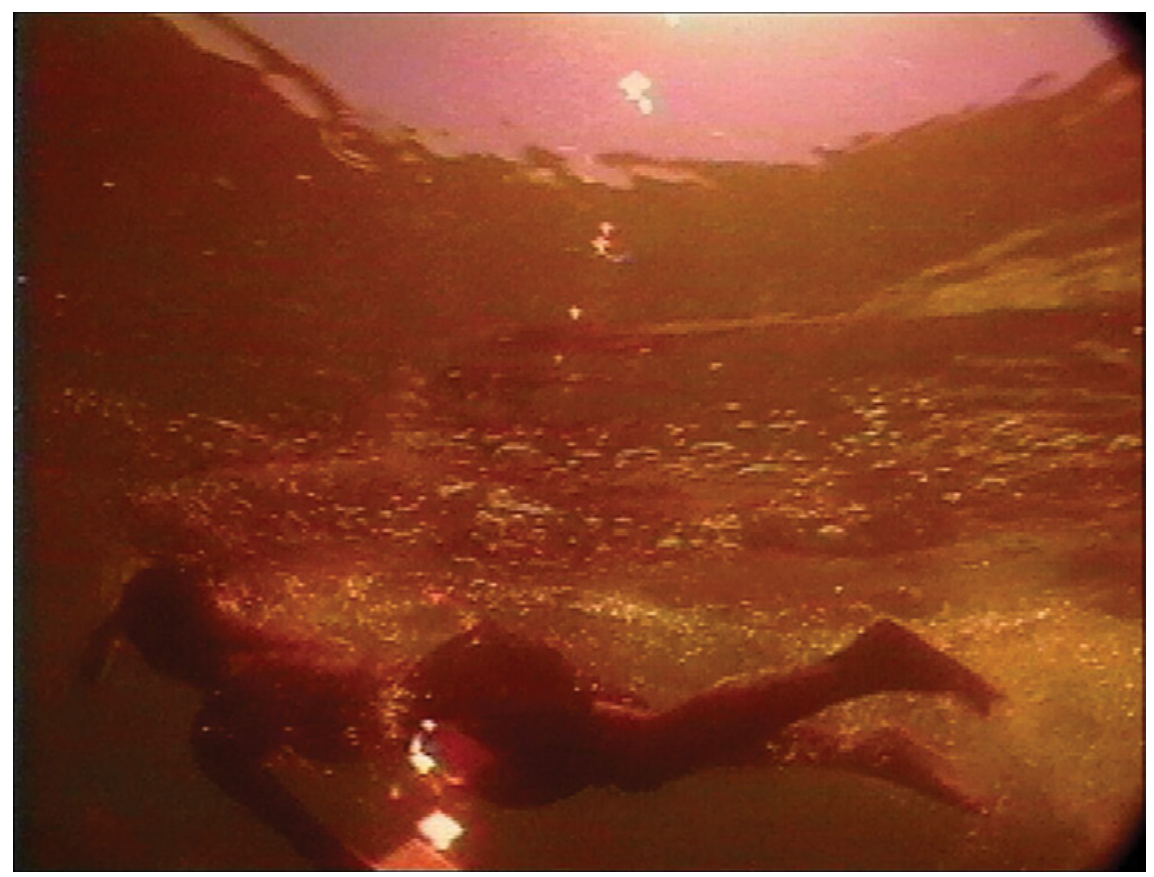

FIGURE 6 Richard Fung, Sea in the Blood, 2000. Film (still), 26 minutes. IMAGE COURTESY OF THE ARTIST.

invoke Lisa Lowe's recent book, The Intimacies of Four Continents (2015). Stereotypes and lived possibilities have their local particularities, but these are in continuous shift and interplay with global and local histories, systems, migrations, and discursive currents that affect not just the designated ethnicity or racial group, but across those constructed as different groups- the history of slavery and indentured labour, for example.

\section{Participants}

Evelyn Hu-Dehart, Professor of History, Director for the Study of Race and Ethnicity in America, Brown University, Providence, Rhode Island, UsA.

Christopher Lee, Associate Professor, Department of English, University of British Columbia, Vancouver, British Columbia, Canada.

C.X. George Wei, Professor and Chair of History, University of Macau, Taipa, Macau, China. 
Marcela Canizo, Researcher, Pontifícia Universidade Católica de São Paulo, Centro de Estudos Orientais, São Paulo, Brazil.

Cecilia Onaha, Professor and Director, Center for Japanese Studies, Department of International Relations, Universidad Nacional de La Plata, Buenos Aires, Argentina.

LOZ (Chiu Yi Chih and Irael Luziano), Performance Artists, São Paulo, Brazil.

Paula Hoyos Hattori, PhD Candidate, Department of Literature, Universidad de Buenos Aires, Buenos Aires, Argentina.

Richard Fung, Artist and Professor, Faculty of Art, Ontario College of Art and Design University, Toronto, Ontario, Canada. 